\title{
Infectious Spondylodiscitis in the Elderly in a Rheumatological Setting in Togo
}

\author{
Kodjo Kakpovi1 ${ }^{*}$, Awaki-Esso Atake², Prenam Houzou², Issa Diallo3, Mamadou L. Diallo1, \\ Viwale E. Koffi-Tessio3, Komi C. Tagbor4, Sadat Oniankitan', Pahimi Yibe 3 , \\ Erika Djougnwe Mba4, Moubarak Tiadjeri3 ${ }^{3}$ Eyram Fianyo ${ }^{4}$, Owonayo Oniankitan 3 , \\ Moustafa Mijiyawa ${ }^{3}$
}

\author{
${ }^{1}$ Department of Rheumatology, Regional Hospital of Kara, Kara, Togo \\ ${ }^{2}$ Department of Rheumatology, University Teaching Hospital of Kara, Kara, Togo \\ ${ }^{3}$ Department of Rheumatology, University Teaching Hospital Sylvanus Olympio, Lomé, Togo \\ ${ }^{4}$ Department of Rheumatology, District Hospital of Bè, Lomé, Togo \\ Email: `kakpovik@yahoo.fr, awakiatake26@gmail.com,h_prenam@yahoo.fr, issadiallo643@gmail.com, \\ diallolaminemodric6842@gmail.com, anitess2005@gmail.com, tcyrille18@yahoo.ca, sadatoniankitan@gmail.com, \\ florencepahimi@gmail.com,mbaerikamba@gmail.com, tiadjerimoubarak@gmail.com, efianyo@gmail.com, \\ owonayo@yahoo.com,moustafa.mijiyawa@gouv.tg
}

How to cite this paper: Kakpovi, K., Atake, A.-E., Houzou, P., Diallo, I., Diallo, M.L., Koffi-Tessio, V.E., Tagbor, K.C., Oniankitan, S., Yibe, P., Mba, E.D., Tiadjeri, M., Fianyo, E., Oniankitan, O. and Mijiyawa, M. (2022) Infectious Spondylodiscitis in the Elderly in a Rheumatological Setting in Togo. Open Journal of Rheumatology and Autoimmune Diseases, 12, 1-8.

https://doi.org/10.4236/ojra.2022.121001

Received: November 4, 2021

Accepted: December 12, 2021

Published: December 15, 2021

Copyright $\odot 2022$ by author(s) and Scientific Research Publishing Inc. This work is licensed under the Creative Commons Attribution International License (CC BY 4.0).

http://creativecommons.org/licenses/by/4.0/

\begin{abstract}
Infectious spondylodiscitis in the elderly is a diagnostic and therapeutic emergency. They are mainly a functional and sometimes vital prognosis issue, with long-term chronic disabling sequelae and significant social costs. Study aim: To describe the epidemiological, clinical, paraclinical, therapeutic and evolutionary aspects of infectious spondylodiscitis in the elderly in a rheumatological setting in Togo. Patients and methods: This was a multicenter, crosssectional study conducted on the records of patients aged at least 65 years, suffering from infectious spondylodiscitis and hospitalized in four rheumatology units from their respective opening dates till December 31, 2020. Data collection lasted three months (December 1, 2020 to February 29, 2021). The diagnosis of infectious spondylodiscitis was radioclinical and laboratory-based. Results: 83 (49 women, 34 men) of the 1281 patients (6.48\%) examined had infectious spondylodiscitis. The mean age at consultation was $70.59 \pm 5.09$ years, and the mean duration of the clinical course was 12 months. Spondylodiscitis was of tuberculous etiology (89.20\%). It was most often found in the lumbar (56.62\%) and dorsal (21.69\%) segments. The location was multifocal in $12.05 \%$ of cases. It was associated with pulmonary involvement in $22.64 \%$ of cases. A neurological complication was identified in $48.19 \%$. The main risk factors identified were promiscuity (48.82\%), chronic alcoholism (18.07\%), HIV infection (8.43\%), diabetes (6.03\%) and sickle cell disease (6.03\%). The clinical course under medical treatment was favorable in 57 patients $(68.68 \%)$.
\end{abstract}


Conclusion: Infectious spondylodiscitis remains a frequent reason for hospitalization, tuberculosis being the most frequent etiology. Multifocal location, deterioration of general condition, gibbosity and neurological complications are exclusive to the elderly subject.

\section{Keywords}

Infection, Tuberculosis, Spondylodiscitis, Aging, Sub-Saharan Africa

\section{Introduction}

According to the World Health Organization (WHO), an elderly person is defined as any person aged 65 or over [1]. In 2018, for the first time in history, people aged 65 and over outnumbered children under five years of age worldwide [2]. The elderly subject population was estimated to be about $697,967,728$ people; that is, $9.09 \%$ of the world population, 3\% in Sub-Saharan Africa and $2.89 \%$ in Togo in 2019 [3]. Globally, people aged 65 and older are growing faster than other age groups; according to statistics from the State of the World Population report, by 2050 , one in six people in the world will be over $65(16 \%)$, compared to one in eleven (9\%) in 2019. In sub-Saharan Africa, the number of elderly people will reach 69 million in 2025 and 139 million in 2050 [4]. The rapid increase in the number of elderly subjects is motivating a growing interest in the diagnosis and management of their medical problems [5]. Thus, the health of the elderly is currently at the center of all medico-social and economic concerns [6], as this population of elderly subjects is subject to acute or chronic affections resulting from the factors to which they have been subjected and from the normal aging process [1]. Among these diseases, rheumatological diseases constitute the third most frequent group of diseases in the elderly in the West, after neuropsychiatric and cardiovascular diseases [7] [8]. These rheumatological diseases of the elderly have been little studied in sub-Saharan Africa [9] [10] [11] [12]. Studies on rheumatological diseases in Africa, although often conducted in hospital setting, have established the predominant place of infectious pathology in the elderly [13] [14]. The aim of this study was to describe the epidemiological, clinical, paraclinical, therapeutic and evolutionary aspects of infectious spondylodiscitis in the elderly in a rheumatological setting in Togo.

\section{Patients and Methods}

This was a multicenter, cross-sectional study conducted on the records of patients aged at least 65, suffering from infectious spondylodiscitis and hospitalized in the four rheumatology units of Togo from their respective opening dates till December 31, 2020. Data collection lasted three months (December 1, 2020 to February 29, 2021) and was conducted in two phases, namely: a first phase of selecting patient records through registry analysis; all patients at least 65 years old whose diagnosis of infectious spondylodiscitis was mentioned in the registry 
were selected for our study, and a second phase of analyzing the records of the selected patients in order to collect on a pre-established and pre-tested survey form the information needed for our study. Demographic, clinical, paraclinical, therapeutic and evolutionary data of the patients were collected from their records. The positive diagnosis of infectious spondylodiscitis was radioclinical. The etiological diagnosis was based on the isolation of a germ and/or the analysis of histological lesions and/or a strong suspicion: epidemiological context, existence of another infectious site (pulmonary tuberculosis in particular), typical appearance on imaging, favorable response to antibiotic treatment (probable infection). Due to the limited technical platform, no patient underwent a discovertebral biopsy. Data entry was performed using Sphinx Plus ${ }^{2}$ version 5 software. The data were analyzed using Stata version 16 software with chi-square tests, with significance level set at $\mathrm{p} \leq 0.05$.

\section{Results}

83 of the 1281 patients $(6.48 \%)$ examined had infectious spondylodiscitis. They comprised 49 females (59.04\%) and 34 males (40.96\%) (Table 1). The mean age at consultation was $70.59 \pm 5.09$ years (age range $65-85$ years). The mean age was $69.76 \pm 3.98$ years for females and $71.79 \pm 6.23$ years for males $(p=0.0737)$. The age group 65 - 69 years was the most represented ( 35 cases; $42.17 \%$ ). The mean length of the clinical course was 12 months (range one week - 67.20 months). The length of the clinical course was less than one month in 5 patients (6.02\%), between 1 and 3 months in 24 patients (28.92\%) and more than 3 months in 54 patients $(65.06 \%)$. Low back pain and lumbar radicular pain $(\mathrm{n}=$ 53 ; 63.85\%) were the main reason for hospitalization (Table 2). Clinical and paraclinical manifestations were dominated by deterioration of general condition $(\mathrm{n}=73 ; 87.95 \%)$, neurological complications $(\mathrm{n}=40 ; 48.19 \%)$, gibbosity $(\mathrm{n}=37$; $44.58 \%)$ and multifocal location ( $\mathrm{n}=10 ; 12.04 \%$ ) (Table 3$)$. Spondylodiscitis lesions were found on standard radiography in $81.92 \%$ of cases, on computed tomography scans in $16.86 \%$ of cases, and on magnetic resonance imaging (MRI) in $8.43 \%$ of cases. Three cases $(3.61 \%)$ of spondylitis were confirmed on radiography. The tuberculosis origin of infectious spondylodiscitis (Pott's disease) was considered probable in 63 patients $(85.14 \%)$ and certain in 11 patients (14.86\%). The role of a pyogenic bacterium was confirmed in two cases $(22.22 \%)$ and considered probable in seven cases (77.78\%). The pathogens identified were Mycobacterium tuberculosis (11 cases), Staphylococcus aureus (one case) and Escherichia coli (one case). At least one risk factor was present in 65 patients (78.31\%) of whom 37 (44.58\%) had at most two or three factors. The main risk factors identified were promiscuity (48.19\%), chronic alcoholism (18.07\%), HIV infection (8.43\%), diabetes (6.03\%) and sickle cell disease (6.03\%) (Table 4). The clinical course with 12 months of antituberculosis therapy or under two months of triple broad-spectrum antibiotic therapy, depending on the etiology, was favorable in 57 patients $(68.66 \%)$. The various neurological complications regressed under medical treatment (100\%) associated with a plaster corset $(56.62 \%)$ 
Table 1. Socio-demographic data of patients with infectious spondylodiscitis.

\begin{tabular}{|c|c|c|}
\hline & Number of patients & Percentage \\
\hline \multicolumn{3}{|l|}{ Sex } \\
\hline Female & 49 & 59.04 \\
\hline Male & 34 & 40.96 \\
\hline \multicolumn{3}{|l|}{ Socio-economic level } \\
\hline Low & 40 & 48.19 \\
\hline Medium & 24 & 28.92 \\
\hline High & 19 & 22.89 \\
\hline \multicolumn{3}{|l|}{ Statut matrimonial } \\
\hline Married & 53 & 61.03 \\
\hline Widower & 26 & 31.33 \\
\hline Single & 2 & 2.41 \\
\hline Divorced & 2 & 2.41 \\
\hline \multicolumn{3}{|l|}{ Occupation } \\
\hline Farmer & 22 & 26.51 \\
\hline Retired & 21 & 25.30 \\
\hline Housewife & 17 & 20.48 \\
\hline Shopkeeper & 16 & 19.28 \\
\hline Private individual & 4 & 4.81 \\
\hline Mason & 2 & 2.41 \\
\hline Driver & 1 & 1.21 \\
\hline
\end{tabular}

Table 2. Distribution of 83 elderly subjects by reason for hospitalization.

\begin{tabular}{ccc}
\hline & Number & Percentage (\%) \\
\hline Low back pain/Lumbar radicular pain & 53 & 63.85 \\
Functional Impotence & 18 & 21.69 \\
Dorsalgia & 13 & 15.66 \\
Dorsolumbar radicular pain & 11 & 13.25 \\
Dorsolumbar pain & 5 & 12.05 \\
Intercostal neuralgia & 3 & 3.62 \\
Cervicobrachial neuralgia & 1 & 1.21 \\
\hline
\end{tabular}

and after functional rehabilitation (74.69\%). The mean length of hospitalization was $32.93 \pm 22.28$ days (range 5 - 113 days). Three patients (3.05\%) died and 21 patients (11.83\%) were lost to follow-up. 
Table 3. Clinical and paraclinical manifestations observed in 83 elderly subjects with infectious spondylodiscitis.

\begin{tabular}{|c|c|c|c|}
\hline & $\begin{array}{c}\text { Tuberculous } \\
\text { spondylodiscitis } \\
\text { (n=74 cases) } \\
\text { Number }(\%)\end{array}$ & $\begin{array}{c}\text { Pyogenic } \\
\text { spondylodiscitis } \\
(\mathrm{n}=9 \text { cases }) \\
\text { Number }(\%)\end{array}$ & Probability \\
\hline Progessive installation & $52(70.30)$ & $5(55.60)$ & 0.3721 \\
\hline Inflammatory pain & $37(50)$ & $2(22.22)$ & 0.1168 \\
\hline Mechanical pain & $25(33.78)$ & $7(77.78)$ & 0.0109 \\
\hline Mixed pain & $10(13,51)$ & 0 & 0.2425 \\
\hline Lumbar seat & $42(56.76)$ & $5(55.6)$ & 0.9475 \\
\hline Dorsal seat & $16(21.62)$ & $2(22.22)$ & 0.9673 \\
\hline Dorsolumbar hinge & $4(5.41)$ & 0 & 0.4771 \\
\hline Lumbosacral hinge & $2(2.70)$ & $2(22.22)$ & 0.0103 \\
\hline Multifocal location & $10(13.51)$ & 0 & 0.2425 \\
\hline Overall stiffness & $39(52.70)$ & $8(88.88)$ & 0.0398 \\
\hline Abscess & $13(17.56)$ & $2(22.22)$ & 0.7331 \\
\hline Gibbosity & $35(47.30)$ & $2(22.22)$ & 0.1554 \\
\hline Fever & $9(12.16)$ & $4(44.44)$ & 0.0127 \\
\hline $\begin{array}{c}\text { Deterioration of } \\
\text { the general condition }\end{array}$ & $65(87.83)$ & $8(88.88)$ & 0.9243 \\
\hline Radicular syndrome & $47(63.51)$ & $7(77.78)$ & 0.3994 \\
\hline Neurological complications & $37(50)$ & $3(33.33)$ & 0.3476 \\
\hline $\mathrm{ESR}^{\alpha} \geq 20 \mathrm{~mm}$ & $59(79.73)$ & $8(88.88)$ & 0.5137 \\
\hline
\end{tabular}

$\alpha$ Erythrocyte Sedimentation rate.

Table 4. Risk factors in 83 elderly subjects with infectious spondylodiscitis.

\begin{tabular}{cccc}
\hline & $\begin{array}{c}\text { Tuberculous } \\
\text { spondylodiscitis } \\
(74 \text { cas })\end{array}$ & $\begin{array}{c}\text { Pyogenic } \\
\text { spondylodiscitis } \\
(9 \text { cas })\end{array}$ & $\begin{array}{c}\text { Infectious } \\
\text { spondylodiscitis } \\
(83 \text { cas })\end{array}$ \\
$\mathrm{N}(\%)$ & $2(22.22)$ & $40(48.19)$ \\
\hline $\begin{array}{c}\text { Low socio-economic } \\
\text { level and promiscuity }\end{array}$ & $38(51.35)$ & $2(22.22)$ & $15(18.07)$ \\
Ethylism & $13(17.56)$ & 0 & $7(8.43)$ \\
HIV* infection & $7(9.45)$ & 0 & $5(6.03)$ \\
Diabetes & $5(6.75)$ & $1(11,11)$ & $5(6.03)$ \\
Sickle cell disease & $4(5.40)$ & 0 & $1(1.20)$ \\
Malignant tumors & $1(1.35)$ & 0 & $1(1.20)$ \\
Bone surgery & $1(1.35)$ & 0 & $1(1.20)$ \\
Local trauma & $1(1.35)$ & &
\end{tabular}

${ }^{\star}$ Human immunodeficiency virus. 


\section{Discussion}

Infectious spondylodiscitis affects $6.48 \%$ of elderly rheumatic subjects, with a female predominance. The manifestations are dominated by the deterioration of the general condition, low back pain and lumbar radicular pain, neurological complications, gibbosity and multifocal involvement. Tuberculosis was the most common etiology (89.2\% of cases), characterized by the high frequency of advanced forms. Despite the shortcomings (retrospective nature, hospital-based recruitment, narrow technical platform), this high incidence is evidence of the predominant place of infectious spondylodiscitis in the elderly in rheumatological practice in Africa [10] [12] and west [15] [16]. Multifocal involvement [17], deterioration of the general condition [13], gibbosity [10] neurological complications [13] [17], low rate of recourse to surgery [17] [18] are exclusive to the elderly; whereas, fever [19] [20] [21], monofocal involvement [17] [20] [21] [22], and high rate of cure [19] [21] are more frequent in young subjects and those of all ages in the literature. Whatever the age, their occurrence is independent of sex [10] [20] [23], the clinical course is long [10] [17] [20] [24], the pathogens involved are rarely identified [19] [25] and the reasons for hospitalization are dominated by low back pain and lumbar radicular pain [10] [17] [20]. The long clinical course before consultation (12 months) can be explained on the one hand by the lack of information, underdevelopment (difficulties of geographical access to care structures, limited technical platform, lack of financial means) and on the other hand by prior indiscriminate antibiotic therapy and recourse to traditional healers.

The important contribution of X-ray in our study (81.92\%) could be explained by the delay in consultation (long clinical course). X-ray thus retains its place in the diagnosis of infectious spondylodiscitis and remains accessible. On the other hand, the low use of CT scan (16.86\%) and MRI (8.43\%) in our study could be explained on the one hand by their high cost (CT scan costs 60,000 CFA (USD 120 ), and the cost of MRI, set up in 2006, varies from 150,000 CFA (USD 300) to 280,000 CFA (USD 560)) and on the other hand, by the low income of the population: the monthly minimum wage is 35,000 CFA (USD 70) in Togo. It should be added that the National Health Insurance Institute started its operations on March 1, 2012 throughout the Togolese national territory, for civil servants [26].

The main risk factors such as promiscuity, chronic alcoholism, HIV infection, diabetes and sickle cell disease were found in other African studies [10] [17] [19] [20] [27] unlike in the West where iatrogenic causes and chronic inflammatory rheumatic diseases are the main risk factors associated with osteoarticular infections [18] [28].

Improving the living conditions of the population, early diagnosis and management will reduce the frequency of infectious spondylodiscitis in sub-Saharan Africa.

\section{Conclusion}

Infectious spondylodiscitis remains a frequent reason for hospitalization, with 
tuberculosis being the most frequent cause. Multifocal involvement, deterioration of the general condition, gibbosity and neurological complications are exclusive to the elderly subject.

\section{Conflicts of Interest}

The authors declare no conflicts of interest regarding the publication of this paper.

\section{References}

[1] OMS (Genève: Suisse) (2010) World Health Organization. Definition of an Elderly or Aged Person. [Google Scholar] http://www.who.int/healthinfo/survey/ageingdefnolder/en/index.html

[2] World Bank. Population Aged 65 and Over. https://donnees.banquemondiale.org/indicator/SP.POP.65UP.TO.ZS

[3] World Population Ageing 2019: Highlights_United Nations https://www.un.org/en/development/desa/population/

[4] Kouame, A. (1990) Population Aging in Africa. IRDC, Hull.

[5] Gabay, C. (2001) Polyarthritis and Late-Onset Connective Tissue Disease. Revue Médicale Suisse, 3, 212-223.

[6] World Health Organization. Ageing and Health. https://www.who.int/news-room/fact-sheets/detail/ageing-and-health

[7] Wong, R., Davis, A., Badley, E., Grewal, R. and Mohammed, M. (2010) Prevalence of Arthritis and Rheumatic Diseases around the World: A Growing Burden and Implications for Health Care Needs. In: Models and Care, Arthritis Community Research Evaluation Unit, Toronto, 80-110.

[8] Research Directorate, Evaluation Studies and Statistics. The Pathologies of Elderly People Living in Institutions. http://drees.socialsante.gouv.fr/IMG/pdf/er494.pdf

[9] Ouedraogo, D.D., Bori-Bata, F. and Drabo, Y.J. (2011) Elderly and Rheumatological Diseases in Rheumatology Consultation in Burkina Faso (West Africa). Revue du Rhumatisme, 78, 1209-1210.

[10] Diomandé, M., Eti, E., Ouali, B., Kouakou, E.S., Ouattara, M.Y., Kouassi, J.M.D., et al. (2015) Profile of Osteoarticular Diseases in Elderly Black Africans: 157 Cases Seen in Abidjan. La Tunisie medicale, 93, 312-315.

[11] Kakpovi, K., Koffi-Tessio, V.E.S., Houzou, P., Agbevide, K., Fianyo, E., Tagbor, K.C., et al. (2018) Rheumatological Disorders of the Elderly in a Rheumatologic Consultation in Lome (Togo). La Revue de Gériatrie, 43, 31-33.

[12] Kamissoko, A.B., Traoré, M., Oniankitan, S., Wann, T.A., Diallo, M.L., Dakeyo, H.C.M., et al. (2019) Profile of Rheumatic Diseases of the Elderly in Guinea. ESJ, 15, 42-53.

[13] Grassa, R., Anoun, J.M., Thabet, D.E.H., Abid, F., Ben Fredj, I.A., Rezgui, C., et al. (2019) Does Infectious Spondylodiscitis in the Elderly Have the Same Profile as in the Young Subject? La Revue de Médecine Interne, 40, 111-112. https://doi.org/10.1016/j.revmed.2019.10.140

[14] Gras, J., Zarrouk, V., Dubée, V., Lopes, A., Leflon, V., Guigui, P., et al. (2017) Clinical Characteristics and Prognosis of Pyogenic Spondylodiscitis in Subjects over 75 Years of Age. Médecine et Maladies Infectieuses, 47, 82-87. https://doi.org/10.1016/j.medmal.2017.03.212 
[15] Ponciano, A., Cruz, G., Ventura, C., Rabadão, E. and Saraiva da Cunha, J. (2018) Infectious Spondylodiscitis: 5-Year Analysis of a Tertiary Hospital in Portugal. Infectious Diseases, 50, 637-639. https://doi.org/10.1080/23744235.2017.1419374

[16] Homagk, L., Marmelstein, D., Homagk, N. and Hofmann, G.O. (2019) SponDT (Spondylodiscitis Diagnosis and Treatment): Spondylodiscitis Scoring System. Journal of Orthopaedic Surgery and Research, 14, Article No. 100. https://doi.org/10.1186/s13018-019-1134-9

[17] Zomalheto, Z., Kohossi, C., Dossou-Yovo, H. and Gounongbé, M. (2017) Aspects épidémiologiques et thérapeutiques du mal de Pott du sujet âgé: Étude comparative avec la forme du sujet jeune dans la population béninoise. Revue du Rhumatisme, 84, 154-155.

[18] Grammatico Guillon, L., Baron, S., Desenclos, J., Rusch, E. and Besnier, J. (2007) Epidemiology of Infectious Spondylodiscitis in France: The Contribution of the Medical Information Systems Program (PMSI), 2002-2003. Bulletin épidémiologique Hebdomadaire, 43, 367-370.

[19] Kodjo, K., Eyram, F., Komi, T.C., Kokouvi, E., Viwalé, K.E.S., Awaki-Esso, A., et al. (2021) Profile of Osteoarticular Infections among Rheumatology Inpatients in Lome, Togo: A Multicenter Experience. African Journal of Rheumatology, 9, 45-48.

[20] Oniankitan, O., Bagayogo, Y., Fianyo, E., Koffi-Tessio, V., Kakpovi, K., Tagbor, K.C., et al. (2009) Spondylodiscitis at Hospital Outpatient Clinic in Lome (Togo). Medecine Tropicale, 69, 581-582.

[21] Houzou, P., Atake, A.-E., Kakpovi, K., Koffi-Tessio, V.E., Tagbor, K.C., Fianyo, E., et al. (2021) Profile of Infectious Spondylodiscitis in Rheumatology Consultation at University Teaching Hospital of Kara, Togo. Open Journal of Rheumatology and Autoimmune Diseases, 11,160-168. https://doi.org/10.4236/ojra.2021.114017

[22] Zohoun, A., Ngoh Akwa, E., El Ochi, M., Oragwu, N., Akhaddar, A., Albouzidi, A., et al. (2012) Bacteriological Features of Infectious Spondylodiscitis at Mohammed V Military Teaching Hospital of Rabat. Brazilian Journal of Microbiology, 43, 1327 1331. https://doi.org/10.1590/S1517-83822012000400013

[23] Abla, H.B., Ben, M.I., Saidane, O., Ben Tekaya, A., Tekaya, R. and Abdelmoula, L. (2017) Neurological Complications of Infectious Spondylodiscitis. La Revue de Médecine Interne, 38, A247. https://doi.org/10.1016/j.revmed.2017.10.280

[24] N'soundhat, N.E.., Moyikoua, R., Mpika, G.M., Ntsiba, H. and Bileckot, R. (2019) Morphological Aspects of Pott's Disease in Adult Congolese Patients Living in Brazzaville. Health Sciences and Disease, 25, 64-67.

[25] Houzou, P., Oniankitan, O., Koffi-Tessio, V.E.S., Fianyo, E., Kakpovi, K. and Mijyawa, M. (2014) Profile of Pott's Disease in Rheumatologic Consultation in Lome (Togo). Journal de la Recherche Scientifique de P Université de Lomé (Togo), 16, 495-499.

[26] INAM: Institut National of Health Insurance of Togo. History of the Institut National of Health Insurance|INAM Togo. https://inamtogo.com/

[27] Zomalheto, Z., Kobelembi, A., Agbodandé, A., Dossou-Yovo, H., Zossoungbo, F. and Avimadjé, M. (2015) Epidemiological, Clinical and Therapeutic Profile of Spondylodiscitis with Common Germs in Hospital Consultations in Cotonou (Benin). $\mathrm{Me}$ decine ${ }^{\prime}$ Afrique Noire, 62, 405-410.

[28] Lemaignen, A., Buzelé, R., Druon, J., Bémer, P., Gras, G., Arvieux, C., et al. (2015) Osteoarticular Infections in Children and Adults. Rev Prat., 65, 1-11. 